\title{
TOPONYMS AND THE POLITICAL AND ETHNIC IDENTITY IN SERBIA
}

\author{
LJUBIŠA RAJIĆ \\ University of Belgrade ${ }^{1}$
}

\section{AB S T R ACT}

In the course of the last 150 years about 25 place-name changes have taken place in Belgrade. Some were more significant than others, and some of the renamed places have suffered as many as six name changes. These changes are part of a blanket process that includes renaming of state administration institutions, research institutes, schools, universities, factories, museums, sport clubs, etc., as well as personal names. This process reflects political, economic, demographic, and cultural changes serving the purpose of constructing and reconstructing political, ethnic, religious, and cultural identity, as well as political relations, and history. In this paper the author discusses this renaming process, its causes and consequences, as well as its potential for constructing and reconstructing reality.

\section{[1] AN ADDITIONAL FUNCTION OF TOPONYMS}

Toponyms may be classified according to their various functions. Peter Hallaråker (Hallaråker 1997, 163-174) has suggested following five functions: 1) the address function; 2) the linguistic function; 3) the topographic function; 4) the cultural function; 5) the social and psyhcological function; 6) the fantacy function. I believe that between the cultural and the socio- psyhcological functions an additional function should be inserted, namely the function of creating political and ethnic identity. This function is also in conformity with Thorsten Andersson's (Andersson 1994, 8) classification which includes place names as a mean of ideological communication and builder of social belonging. Following up this view, I will here focus on how political, ethnic and cultural changes have impacted the change of toponyms, especially hodonyms, in Serbia. For space reasons I leave out the names of private villas, buildings and other real estates although they would be of great interest in this context.

Microtoponymy has not been researched much in Serbia, and (h)odonymy (cf. (h)odonym 'proper noun of a traffic route feature') is subject for - as far as I know - only three articles (Josić 1996; Dulović 2004; Stojanović 2008). But no one of

[1] Ljubiša Rajić deceased a short time before the publication of this volume, see Author Contact Information. 
them is to be fully trusted: Josić (1996) is already somewhat out-dated, Dulović (2004) is an informative, but very short overview, and Stojanović (2008) has a lot of information, but also some wrong, and is not enough systematic. There is no central register of toponyms while the available printed and electronic maps do not cover the entire country (see f. ex. electronic maps Geografska (2007) and Contrast-PlanPlus10 (2008)). Further, the changes of toponyms are often recorded with a delay of several years, and then they are not to be found in any public form except for those living in the area in question.

When streets and squares are renamed due to some changes in the society the new names usually replace the old ones, which often results in wiping them out. It is very rare that a new name plate is added beneath the old one, and when this occurs it is regarded as an exception to the general practice. For this reason it is difficult to reconstruct a more or less comprehensive list of toponyms and their changes over time. But they get a part of a modern history, contrary to what Tarpley (1996) claims. So, we have to go back to more popular surveys of the street names in f.ex. Belgrade (see Stojanović 2004, 2005; Golubović 2006; Leko 2006) or look for historical monographs (cf. Tasić 1995; Stojanović 2008).

Preservation or changing of toponyms depends on an array of factors. The interplay of linguistic and historical, as well as cultural and historical factors in the development of toponyms has been covered fairly well by the general toponomastic literature. Notwithstanding, in the field of sociotoponymy appropriate literature is limited, while the research of the function of toponyms as an instrument of identity building is even harder to come by. In Serbia this kind of research has hardly been done at all, which may be due to the fact that these fields of research are relatively new. For this reason my primary sources of relevant information came, for the most part, from the news concerning place-name changes that appeared in the media, and from my students who informed me about the renaming processes that have taken place in their home towns. My secondary source material comes from a student's research paper and several books that address place-name changes in Belgrade. A more general toponomastic research problem across the Balkans is, for the most part, that the local scholars who engage in this research either lean towards nationalistic interpretation of the material, or do not belong to the top echelons of onomastics, or both. In certain situations this may challenge the reliability of the data acquired from their research.

Renaming often takes place during critical times in history, and in such times it usually occurs wholesale. A few series of place-name changes took place in the former Yugoslavia during war 1992-1999 and in post-war construction of new reality, see also Rihtman-Auguštin (2000 [1995]) for Croatia generally, Stolac (1996) for Croatian coastal town Rijeka, Memić (2008) for Bosnia-Hezegovina, Piškorec (2008) for a small town in Croatia, and above mentioned literature which in whole or partially deals with the hodonymy of Belgrade), and sometimes it is easy to 
see this kind of close connection even in the titles of some analyses (for example Memić and Piškorec, op. cit.). As a rule it is easy to see an obvious correlation between external political, economic, demographic and cultural changes and their reflection in the renaming of toponyms. This applies not only to the former Yugoslavia, but also to other parts of Europe (see Azaryahu 1991, Eller, Hackl, Pupták 2008, Lietz 2009; David 2011) and worldwide (Tarpley 1996).

Obviously we here have a global phenomenon, but the majority of examples I will provide in this paper belong to the pool of street and square names as well as the names of boroughs and neighborhoods of Belgrade, but I will also give other examples of naming and renaming to support the point I want to make.

\section{[2] THE City AS A SYMBOLIC SPACE}

Belgrade was a fortified frontier city which has had an extremely turbulent history. In 1848 when the Turkish occupation authorities allowed for the first time that the city streets were given permanent names Belgrade had only 30 streets, of which 19 were given generic descriptive names while the remaining 11 were named after the heroes of the First and Second Serbian Uprising of 1804 and 1813 respectively. However, it was not before 1872 - when the Turkish forces withdrew from Belgrade pursuant to the Treaty of 1868 - and 1878 when the Turkish forces withdrew from the Belgrade fortress - that the street name plates were mounted. Following Turkish withdrawal the number of city streets grew to 176, and, since that time, the streets and squares of Belgrade have been renamed about 25 times. Each time the new names symbolized the changed political, ethnic and cultural circumstances.

Place names introduced in the late $19^{\text {th }}$ century reflect not only the evolving conflict of the two Serbian dynasties but also the city administration's effort to "modernize" street names. Generic street names such as Pivarska ulica (Brewery Street) and Ribarska ulica (Fishermen's Street) seemed to be outdated and therefore changed. Today, only 30 streets in Belgrade still bear the names that survived this renaming tide. Between 1909 and 1913 the ideas of pan-Slavic unity spread and developed across the entire Southern region of Europe populated by South Slavs. Consequently, a number of old streets suffered a name change to reflect the new flavor of the day, mostly given as topographic names from the South Slavonic area Dalmatinska, Mostarska, Kumanovska, Vardarska, Bitoljska, Vojvođanska, Nevesinjska, Travnička (Dalmatia, Mostar, Kumanovo, Vardar, Bitola, Vojvodina, Nevesinje, Travnik Street), and after 1930 as panslavic anthroponymic names (Mickiewicz, Aleksandar Stambolijski etc.). Similarly, during WW I, the AustroHungarian military authorities carried out a renaming process to "Germanize" place names in the period from July 1916 to November 1918 (for example Moskovska became von Laudon Straße). 
After 1920 Belgrade became the capital of the Kingdom of Serbs, Croats and Slovenians, the state whose government soon decided to rename the state itself. It became the Kingdom of Yugoslavia (Yugoslavia being the name coined to symbolize the unity of South Slavs). This change brought about another wave of renaming of the streets of Belgrade so that the new street names would reflect the spirit of the new state. The enthusiasm for the "spirit of Yugoslavia" was rekindled around 1930, which resulted in renaming of many streets of Belgrade which, this time, were named after Croatian and Slovenian politicians and intellectuals (for example Supilo, Štrosmajer, and others), and politicians and high-ranking officers of both Serbian and allied armed forces who took part in WW I. Partially in 1942, to a wide range from 1943 the German occupying authorities renamed all of the streets whose names could be taken as anti-German such as Engleska ulica (English Street), Jevrejska (Jewish Street), Cara Dušana (Tsar Dusan Street) etc. The new names were Hindenburg, Prinz Eugen, Herman Göring, Gneisenau Straße etc., and in Zemun, which was a part of the Independent State Croatia, Dr. Ante Pavelića (the name of Croatian President and Führer). At the same time the local collaborationist government wiped out all place names that 'smacked' of Yugoslavia.

In 1946, although the renaming of 1943 was officially revoked, some pre-war street names were not returned. This time over 110 streets underwent a name change. Many streets were renamed after fallen members of the Partisan Movement, pre-war activists of the workers' unions, and selected personalities belonging to the Western Allies. Also, a considerable number of the new names reflected a pro-Soviet spirit. However, upon the Cominform Resolution of 1948 these names were changed.

The state itself suffered several name changes which entailed renaming of other places as well. For example, all German village names were replaced by Serbo-Croatian names, and the Yugoslav president's nom de guerre "Tito" became the first element of a new compound name of at least one city in each of the five republics and two autonomous provinces of Yugoslavia. So, the capital of the republic of Montenegro changed its name from Podgorica to Titograd. Further, all cities and towns had to have a street (or place) called Maršala Tita (Marshall Tito's Street), and the first highway spanning Belgrade and Zagreb was named the Autoput bratstva i jedinstva (Highway of Brotherhood and Unity).

Since mid-1950s a new need concerning place names has come into play, and, therefore, the old streets and squares of Belgrade underwent less frequent name changes. As the city grew in size new streets needed to be named. In October 1944 the population of Belgrade was about 240.000 whereas today it is about 1.650.000. New streets have been predominantly named after local and international politicians and other personalities. As the city was growing very fast, many new streets where dubbed Nova ulica (New Street) for purely practical reasons. So, by 2003 there were 658 streets called New Street. To avoid confusion within a neighbor- 


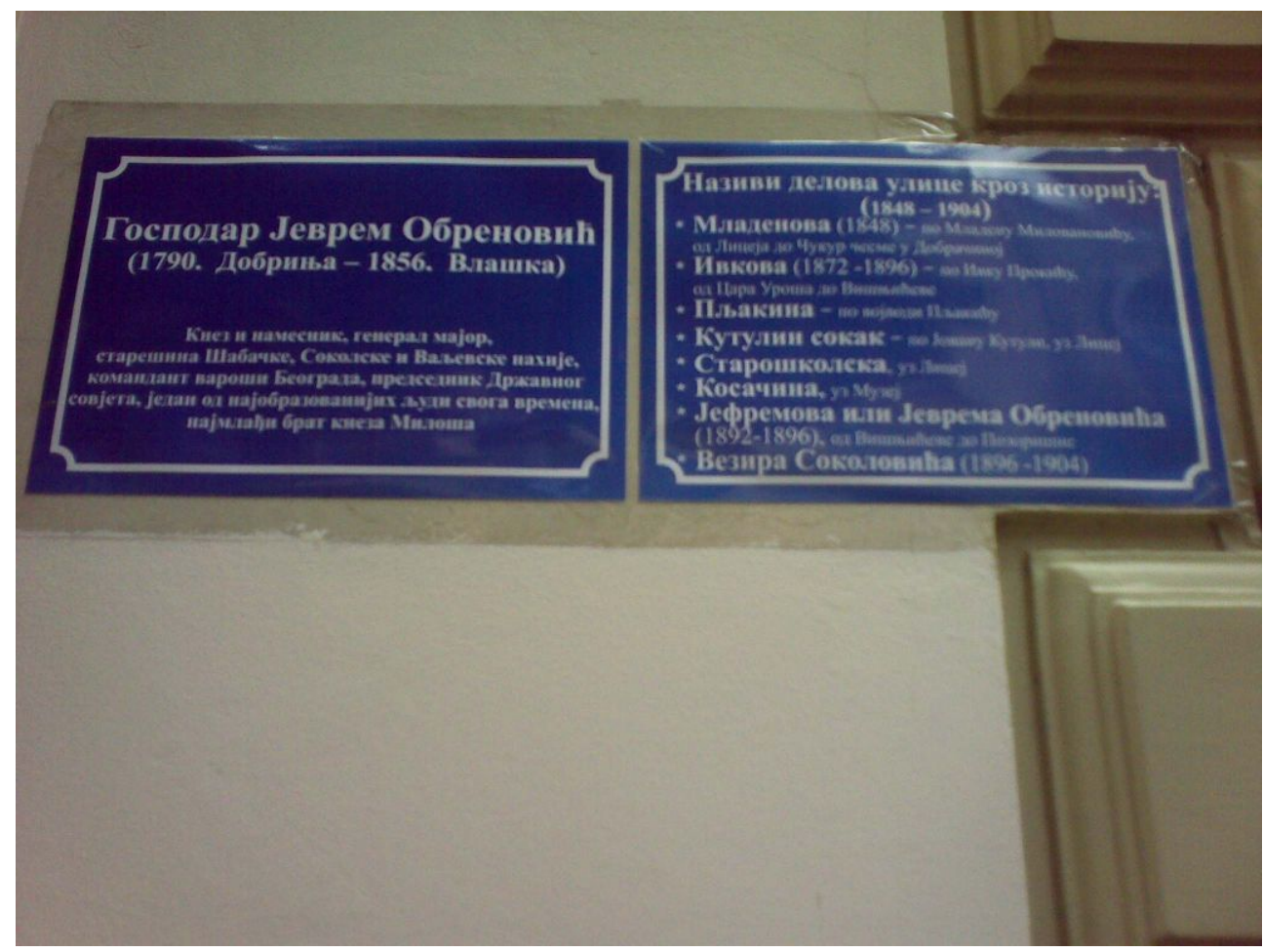

FIGURE 1: Jevremova Street - nine different non-official and official names since 1848.

hood, the names of new streets were often added chronological sequence markers, and the streets became First New Street, Second New Street, Third New Street, etc. Further, as the city grew it "swallowed" a number of neighboring towns and villages which brought with them their own street names. This is why up to 14 streets in broader Belgrade often bear the same name. During the 90s, upon the disintegration of Yugoslavia, a new renaming tide occurred to reflect the new political system in each new country and its new politics. This process had three main objectives: first, to reinstate the street names from before WW II; second, to rename the streets and squares built after WW II; and, third, to name the streets and squares which had no name because they had been recently constructed. This process is still in progress. In 2004 and 2005, for example, the names of about 400 streets and squares were changed in an effort to attain the above objectives, particularly the first two. As for the third objective, the problem was that there were not enough new streets to fulfill the wishes of all political players in power. For this reason numerous streets were split into segments each of which was given a different new name. The political history of toponyms is in fact a reflection of the 
political history of a country. Consequently, place names are to a greate extent, a means for constructing and deconstructing as well as re-interpreting political history. This accounts for the constant reduction of the number of generic and descriptive toponyms as well as the steady increase of street and square names that refer to people. The latter make about $90 \%$ of all place names in Belgrade today. It would be fair to say that, at times, new generic place names still occur particularly when there is a "shortage" of personalities acceptable to all wielders of power. Along these lines, for example, some places have been named after the local flora.

A street not far from my home in Belgrade has undergone eight name changes since 1848 (Figure 1). Another two very close to my home have suffered six name changes since 1872 (Figure 2 and 3), and there is no guarantee as to whether the current name will stay for any length of time. In Belgrade the municipal authorities have the power of deciding whether the plate with a street's old name shall be kept above the new name plate or removed. For example, one of the main streets in central Belgrade was called Maršala Tita (Marshall Tito's Street) from 1946 to 1991. Then it became Srpskih vladara (Serbian Rulers' Street), and, in 1997 it suffered yet another name change and became Kralja Milana (King Milan's Street), thus recovering its pre-WW I name. The name plate with "Marshall Tito" written on it was removed (Figure 4), which can be reasonably explained as an attempt to erase from public memory the name this street bore for 45 years just because it is no longer politically opportune. However, apart from mere negligence, there is no logical explanation for the removal of the former street names in such cases as Drum kragujevački (Kragujevac Road) from 1841-1872, Kragujevačka (Kragujevac Street) from 1872-1888, and Kralja Milana (King Milan's Street) from 1903-1946. Nor is it indicated anywhere that this street incorporated today's Terazije (Terazije Street) from 1888 to 1903.

As a matter of law, every street and square name change proposed by the municipal authorities of Belgrade has to be approved by the ministry in charge of local public administration. In practice, however, the ministry has hardly ever withheld its approval. Therefore, the selection of places to be renamed and the manner in which the change is executed depend on the decisions of the local wielders of political power in any given municipality of Belgrade. During the early 90 s this power was in the hands of extreme nationalists who endeavored, first, to identify anti-fascism with communism, and, second, to remove anything that has to do, or could be even remotely associated with communism. To achieve this they used renaming of streets and squares as a tool for erasing all traces of the anti-fascist movement during WW II as well as the pre-war communist and trade union movements. The fastest and most fundamental changes were made in those municipalities where the extreme right-wing parties were in power. For example, in Aranđelovac, a small town in central Serbia, where the extreme right-wing 


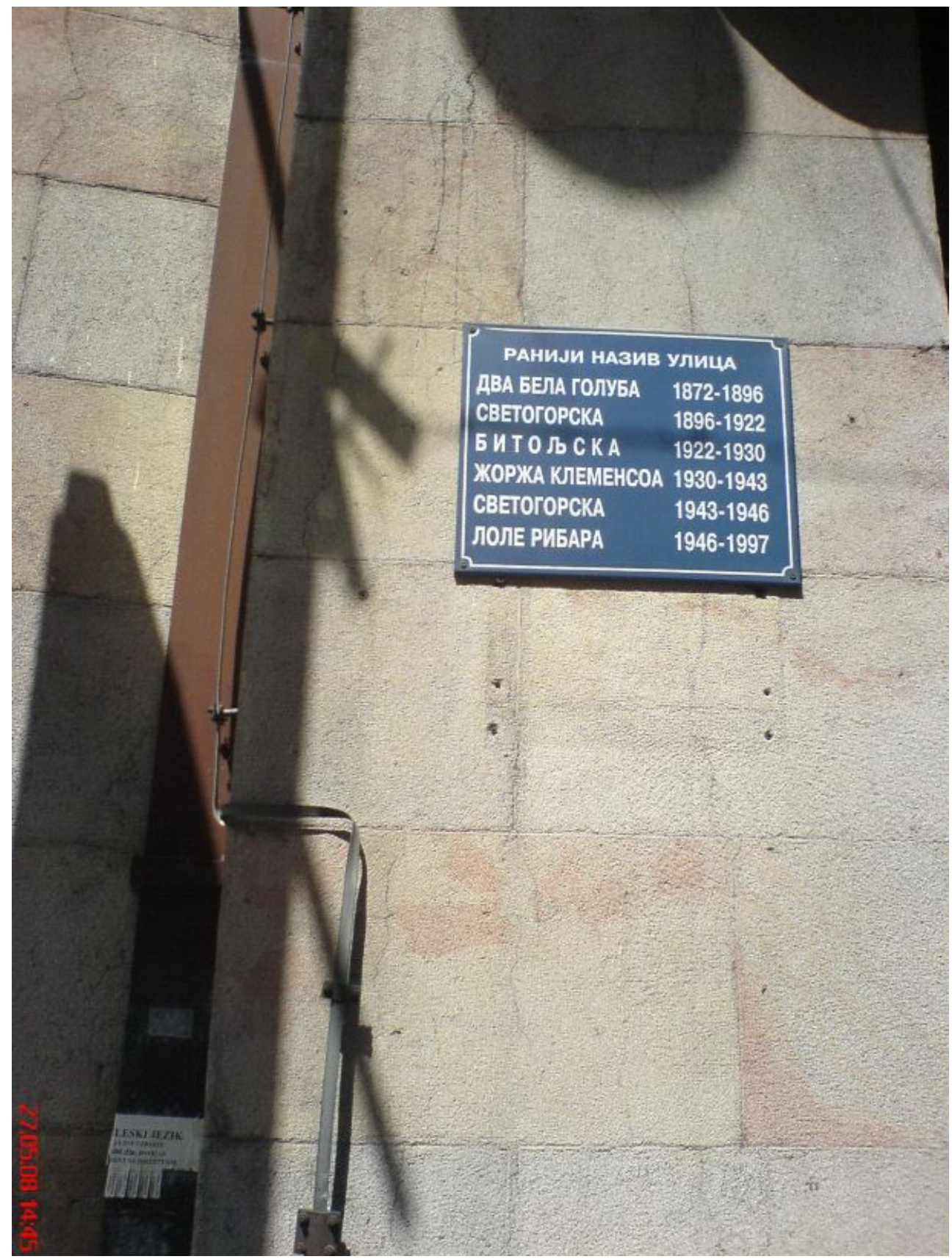

FIGURE 2: Two white pigeons (1872-1896), The Holy mountain Street (1896-1922), Bitola Street (1922-1930), George Clemenceau (1930-1943), The Holy mountain Street (1943-1946), Lole Ribara (1946-1997), The Holy mountain Street (1997-). 


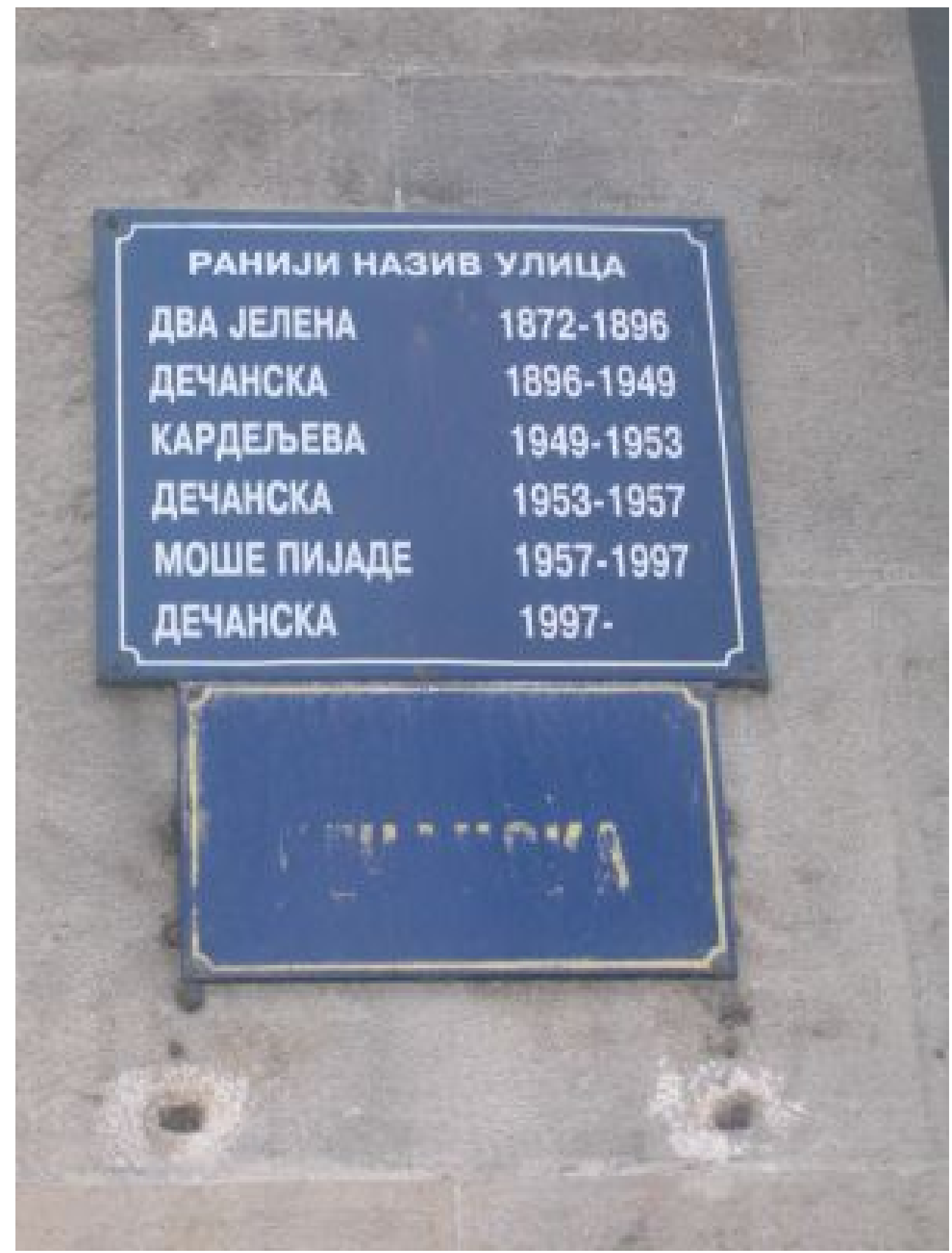

FIGURE 3: Two deers (1872-1896), Decani Street (1896-1949), Kardelj's Street (19491953), Decani Street (1953-1957), Mosa Pijade Street (1957-1997), Decani Street (1997-). 


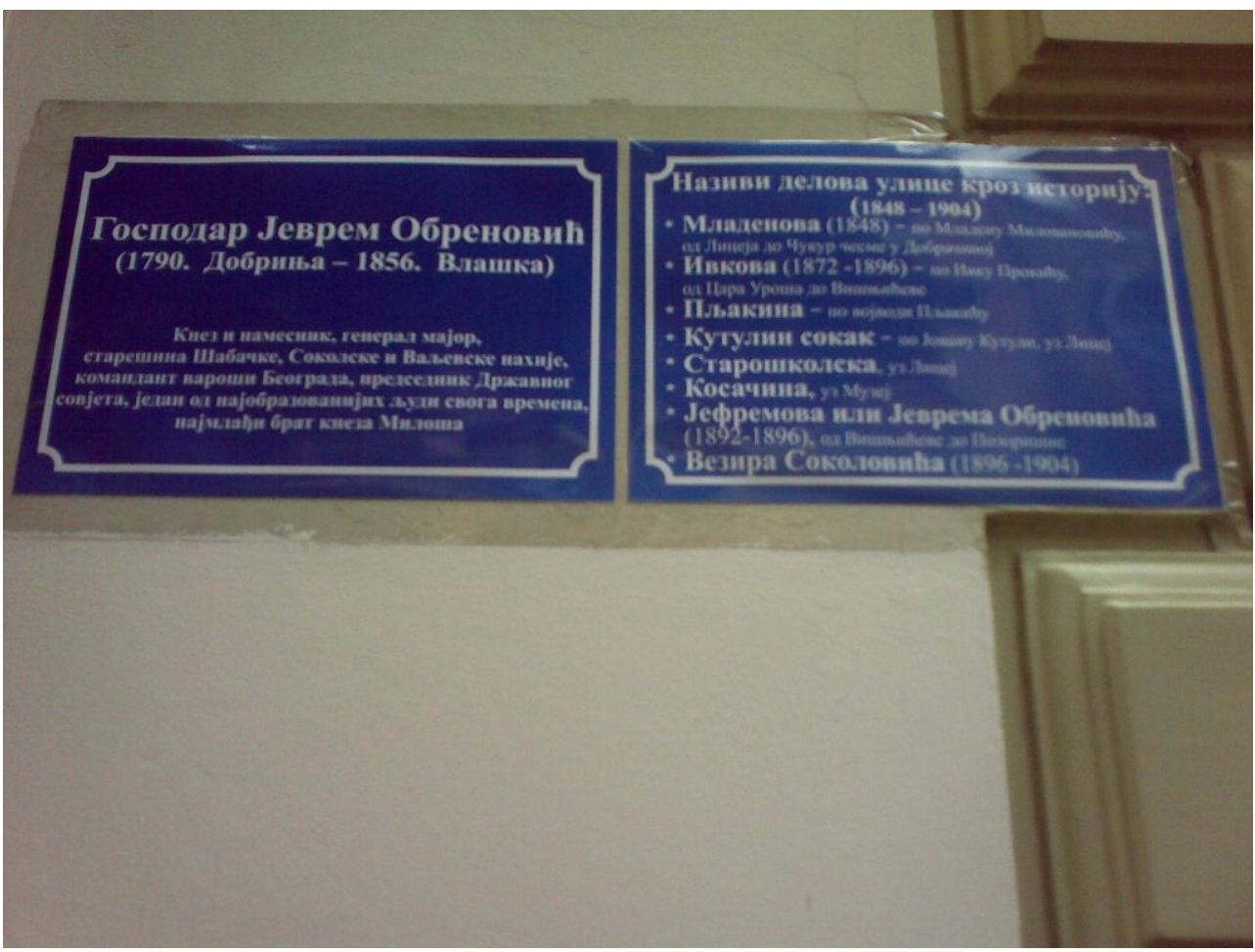

FIGURE 4: King Milan's Street, former The Serbian rulers Street, but no Street sign with Marshal Tito's Street.

parties seized power one of the streets became Đenerala Milana Nedića (General Milan Nedic Street), named after the president of the collaborationist government during WW II.

\section{[3] TOPONYMS AS A SYMBOL OF THE SO CALLED ETHNIC DEMOCRACY}

A similar process has been evolving across Eastern Europe. In the former member states of the Warsaw Pact, however, this process has consistently featured extreme anti-Soviet and anti-Russian feelings. With few exceptions, today's picture of who was who during WW II seems to be turned upside down. Both naming and renaming of streets, squares, institutions, business organizations, etc. have been modified to fit into this new frame. There are relatively few exceptions to this trend. The most noteworthy examples are provided in Slovenia where the majority of existing place names have been preserved, and in Russia where the old street and square names from before the Soviet Revolution have been restored, while the majority of the names of the streets and neighborhoods that developed after the Revolution have been preserved. 
This revision of history has developed within the framework of the so called ethno-democracy, the process by which the ruling ethnic group is granted all democratic rights while other ethnic groups are given restricted democratic rights or are deprived of them. Thus, the role of the new place-names is not only to support the re-interpretation of history but also to impose on it a clear-cut ethnic profile. In support of this process arguments reflecting the ideas of the society set-up referred to as Herrenvolk democracy are often used. (For more details about ethnocracy see for example Butenschøn 1993).

This process is taken a step further when the existing names of settlements are changed to underscore the altered, actual or assumed, ethnic composition of its inhabitants or their political affiliation (see Rihtman-Auguštin 2000 [1995]; Stolac 1996; Memić 2008; Piškorec 2008; Stojanović 2008). This happened when Hrtkovci, a village in North-West of Serbia predominantly populated by Catholic Croats was renamed upon ethnic cleansing of Croats and forced re-settling of ethnic Serbs who had fled or had been expelled from Croatia. The village was coined a new name: Srbislavci which means 'honoring Serbs'. Further, a small town in Bosnia called Foča was renamed and became Srbinje, meaning 'belonging to the Serbs, right after its Moslem population was either expelled or killed. This process of ethnic profiling of place names is actually quite simple. For example, Kukujev$c i$, a village on the Serbian border with Croatia, was populated predominantly by Catholic Croats. The majority of this group was forced to move to Croatia during the '90s. Meanwhile the village was steadily populated by the Christian Orthodox Serbs, refugees from Croatia, and Bosnia and Herzegovina. This resulted in the current composition of the village population whose vast Serbian majority is extremely right-winged and chauvinistic, and shares the most backward ideas of the Serbian Orthodox clergy. By the beginning of November 2007 the village authorities decreed renaming of all the streets which bore the names of famous people from Croatian history. Not surprisingly, these streets were given new names of famous people from Serbian history. The authorities knew hardly anything about either group of personalities, but they knew their ethnic origin. In November 2007 the village authorities requested that the village itself be renamed either Lazarevo, after the Serbian prince who had been killed during the Battle of Kosovo in 1389, or Obilićevo after Miloš Obilić, an assumed hero who, according to the oral folk tradition, had killed a Turkish sultan in the same battle, a claim for which there is not a shred of historical evidence. The change request of the filed name was accompanied by a very simple statement of purpose in which the local authorities said: "We are the majority in the village, which gives us the right to change any place name we choose". A similar situation occurred in another part of Vojvodina, in an ethnically mixed community where the members of the official Hungarian minority constituted the majority in the municipal assembly. In Kanjiža which is a town predominantly populated by ethnic Hungarians it took the local admin- 
istration a single meeting to have no fewer than 134 street names changed. All of the new street names are in Hungarian and reflect the Hungarian view of the history of the town as well as its inter-ethnic relations. Almost all inhabitants albeit for different reasons of which some were political while others were practical (as this would entail replacement of all documents and personal papers) petitioned to challenge this name change. Unfortunately, their effort failed despite the fact that the name change had been voted into effect by mere abuse of the majority vote in the local assembly. Further, in the South of Serbia there are three municipalities bordering on Kosovo where place names are predominantly in Albanian although ethnic Albanians constitute the majority in just two of these municipalities.

Similar processes are under way in all republics of the former Yugoslavia and the province of Kosovo. In Kosovo everything has two very different interpretations: Albanian and Serbian. This is mirrored in place names. The region itself is now referred to as Kosovo although it consists of two parts one of which is called Kosovo in Serbian and Kosova in Albanian. This name is Slavic in origin. The other part of the region is called Metohija which is derived from the Greek word metochion $(\mu \varepsilon \tau o \xi\llcorner O \nu)$ denoting monastery estate. The entire region used to be called Kosovo and Metohija. However, in one of the revised and amended versions of the Constitution of the Socialist Federative Republic of Yugoslavia it was stipulated that the region was to be referred to only as Kosovo, as had been requested by the political elite of Kosovo Albanians who argued that this name would reflect more accurately the Albanian demographic spread in the region. When NATO forces came to Kosovo in June 1999 a thorough "Albanization" of the names of the streets, squares, settlements, businesses and other organizations was carried out in order to define Kosovo as an Albanian region, and the name Metohija ceased to be used as it was officially renamed Dukagjin which is an Albanian word. In Croatia, several streets have been named after Mile Budak, a mediocre Croatian author from the time between the two world wars who was appointed Minister of Education in the Independent State of Croatia - a state created at the beginning of WW II by the German Nazi Occupation Administration - despite the fact that he himself signed a number of racist laws which were put into effect at that time. Different places in Croatia have been renamed after other prominent individuals of that time, the majority of whom belonged to the Croatian nationalist movement and its extreme Nazi division called Ustashi.

A combination of the absence of democratic tradition, disrespect for the cultural and historic significance of toponyms, political interests and complete disregard for the UN recommendations concerning place names has facilitated a seamless three-way merger of "ethno-democracy", a romantic national concept of history, and the outlook on society promoted by the clergy. That type of change can be named as albanization, croatization, islamization, and serbization of the social 
and political space. Not surprisingly, this merger has been causing friction and conflict in multiethnic societies. Meanwhile, the renaming process has taken its toll on both the state and its citizens. City street plans, street name plates, official business licenses, seals and stationary are costly, and so are all personal documents and everything else that needs to be replaced when the address changes. In addition, frequent renaming of streets causes serious confusion when it comes to city services such as medical emergency service, fire brigade, postal, taxi and car services, to say nothing about how it confuses out-of-town visitors and citizens proper who belong to different generations and, therefore, use different street names referring to the same street. Unlike political interests which have been courted and accommodated by every place-name change I know of, the inconvenience street renaming imposes on the citizens, to the best of my knowledge, has not even been considered by any of the authorities. It is true, however, that the mounting of new name plates may be delayed, but that happens, as it did in Kanjiža, only because local authorities may not have enough money to cover the production costs of the new name plates.

\section{[4] TOPONYMS AS POLITICAL AND CULTURAL SYMBOLS, AND EVIDENCE OF HISTORIC RIGHTS}

It is not always easy to think of place names which would meet both ethnic and political requirements, particularly when the education and general intellectual level of many politicians who decide on place name changes are taken into consideration. For this reason there are quite a few surprising place names in Belgrade. The official publication Place Naming Guidelines for Belgrade of March 28, 2003 (Kriterijumi 2003) contains, for the most part, reasonable guidelines. However, some of them are rather imprecise and may be interpreted in different ways. For example, one of the "fuzzy" guidelines reads as follows: "One of the international requirements concerning the capital of SRY is to have some of its streets named after international statesmen, scientists and artists. The streets bearing such names should be located in the attractive city neighborhoods." In practice, the interpretation of this guideline resulted in some sociologically and politically interesting choices. Consequently, the group of international artists after whom Belgrade streets were named includes the writers Mikhail Bulgakov, Rabindranath Tagore, Miguel de Cervantes and Ernest Hemingway as well as their much less significant fellow artists such as the jazz musician Django Rinehardt and movie star Yul Brynner. On the other hand, street names, as per another political decision, should indicate that Belgrade is a Serbian city, and that its streets bear the names of international personalities who have played a role in the history of the Serbian people. This, however, is not the case with any of the above people after whom several streets of Belgrade have been named. 
Interestingly enough, some old streets of Belgrade have preserved their old names although their names are identical to the toponyms in other countries. Such examples include, but are not limited to, Zagrebačka (Zagreb Street) and Dubrovačka (Dubrovnik Street). In addition, some of the preserved street names have suffered a curious transformation, as is the case with Kondina (Kondina Street) in the very center of Belgrade. Ostoja Tom Konda after whom the street was named was a Christian Orthodox Albanian who, like many other Christians, Serbs included, served in the Turkish military forces during the long rule of the Ottoman Empire in the Balkans. During the First Serbian Uprising, namely in 1806, he and his men changed sides and joined the Serbian rebels. During the siege of the Belgrade fort of Kalemegdan Konda and his crew were the first to win entrance to the fort through its main gate. In all likelihood the Serbian rebels would have seized the fort even without Konda's assistance, but this might have cost them greater losses. A plate explaining who Konda was was mounted two years ago at the beginning of the street bearing his name. The text on the plate provides a brief account of his heroic deed and says that he was Christian, but the fact that he was Albanian has been curiously omitted.

In the transition societies toponyms have gained a clear-cut profile of political and cultural symbols. For this reason, in Croatia streets have been named after Hans Genscher, former German Minister of Foreign Affairs who was instrumental in exercising pressure on the international community to grant and recognize Croatia's independence. The same holds true for the reason Bill Clinton has a boulevard in Priština (Kosovo) named after him. In Sarajevo (Bosnia and Herzegovina) many streets now bear oriental names while the street that was named after Ivo Andrić was renamed, and his name wiped out despite the fact that he was Croat from Bosnia and the only Nobel Laureate for Literature from the entire former Yugoslavia. Andrić, who was of Croatian ethnic descent, declared himself as a Serb, which seems to be a reason good enough for the Bosnian nationalists to condemn his entire literary work as being pro-Serbian. The Albanian writer Besnik Skupi authored an article in the May/June 2007 issue of the Kuvendi, a geo-political monthly published in Tirana (Albania), in which he discusses the names of the cities and towns with a sizeable Albanian community, and those whose population is almost entirely Albanian. To make his point he uses the names of Skopje, Skuardi and Shkodër and argues that the phoneme sequence in sku-ska-sko provides direct evidence of the Albanian Illyrian descent as well as pre-Roman demographic presence of Albanians across the Balkans. This, in turn, according to the same author, testifies to the territorial spread of Albanians, which substantiates their right to claim this entire territory. Skupi's article abounds in similar quasi-scientific historical and demographic data, but a single example is enough to show how old toponyms can be (ab)used to support current territorial pretensions. Besnik Skupi is just one of many proponents of what 
many Balkan scholars jokingly refer to as "zombie linguistics", the quasi-science which endeavors to revive the long outdated national-romantic ideas of the past. Still, the spread and impact of this scientific disgrace across the former Eastern Block should not be underestimated because it often surfaces in the amateurs' and politicians' response to the development of socio-onomastics. Worse still, it has been incorporated in general education programs side by side with similar approaches to the content of the courses of national and cultural history. However tempting it may be, addressing this issue any further would take us away from the topic of this paper.

Political interests, dealing and wheeling, prestige and revenge as well as historical revisionism and the lack of knowledge often lie beneath renaming. However, a considerable number of place-names always survive changes. Belgrade was under Turkish occupation for almost 400 years, but its today's street names do not provide any evidence of that. The only remnants of the long-drawn Turkish rule are one mosque, two distinctively Turkish tombs, and several structure blocks of the old Kalemegdan fort and city walls. However, a number of macrotoponyms dating back from the Turkish occupation have survived all the placename changes. For example, during the Turkish rule it was prohibited to smoke a pipe within the city walls for fear that lighting a pipe may start a fire. Smoking a pipe was allowed outside the city walls. In Serbian "pali lula" means 'light a pipe'. This is the story behind the name of one of today's municipalities of Belgrade which is called Palilula. Further, one of Belgrade's old parks is called Topčider, while several city neighborhoods still bear their old names such as Karaburma, Dorćol, Jatagan mala and Bulbulder. The old fort and city walls of Belgrade are called Kalemegdan, and the name of very center of Belgrade, Terazije, is also Turkish. All these names originate from Turkish words, and, indeed, when you say them they sound Turkish.

Similarly, there are place names that are not official but dominate common usage. They, too, tend to resist change. For example, the very central square in Belgrade is called Trg republike (Republic Square). In one of its three corners a monument to the Serbian prince Mihailo who lived and ruled the country in the $19^{\text {th }}$ century, was erected. Prince Mihailo, like all other rulers of the day, was mounted on a horse, as the architectural style and practice required. For this reason, at some point, young people of Belgrade started referring to the entire square as the "Horse Square". Given that this square is one of the favorite meeting spots in the city, many people of Belgrade would normally say they are meeting someone "kod konja" ("at the Horse") rather than "on Republic Square". Such spontaneously coined place names usually resist political will or intention to have them changed. They tend to be passed on from one generation to another, thus becoming not only part of the jargon of the young but also colloquial speech in general. 


\section{[5] OTHER NAMES AS TOPONYM ADD-ONS}

Toponyms are the most important elements of the ethnic and political identity of an area because they define it as a territorial unit, but they are not the only agents of this kind of identity building. Other names may partake in it as well, either independently or as add-ons to the existing toponyms. For example, after WW II many new place names were deliberately evocative of the war and Partisan victory. Thus, many new business organizations were named after the heroes of WW II, or were given more general, but just as evocative, names such as Partizanski put (Partisans' Way).

Upon the fall of the communist regime at the beginning of the 90s, some of these businesses were renamed. For example, in November 2007 there was an initiative in the multiethnic city of Novi Sad to reinstitute the original name of the city's oldest high school. That name had been Srpska pravoslavna velika gimnazija u Novom Sadu (The Serbian Orthodox High School of Novi Sad) before it was revoked in 1918 when the school was named Jovan Jovanović Zmaj after a famous Serbian poet and medical doctor from the $19^{\text {th }}$ century. In addition, the initiative proposed that a regular fountain in the school yard were replaced by a memorial drinking fountain which would feature two mosaics depicting "Christ as a shepherd" and "St. Sava blessing Serbian children". (St. Sava is a Serbian Orthodox saint from the middle ages who is taken to be the patron saint of schools and students at all levels of education.) In Novi Sad, at the time of this initiative the city administration was more or less in the hands of the nationalist Serbian Radical Party. Therefore, the main intention of the members of the city administration who submitted the initiative was to underscore the Serbian ethnic and religious Orthodox spirit of the high school. To prevent the enactment of this initiative the citizens of Novi Sad had to organize public protests and mobilize several political parties into action so that a name which implies that the school is for Serbian students only would not be imposed on a high school that has a multiethnic student body. (For more information refer to www.petitiononline.com/novisad/petition.html).

A similar renaming process of schools, barracks, museums and other public places has been going on in all republics of the former Yugoslavia as well as across the former Eastern Block. Local Nazi collaborators from WW II and historic personalities notorious for promoting extreme nationalist and anti-Semitic ideas have been rehabilitated by means of being granted a place name. In other instances, a part of a place name may be changed, or an ethnonym may be added to it as a significant marker. A good example of such renaming interventions is provided by the name changes of the Jugoslavenska akademija znanosti $i$ umjetnosti (Yugoslav Academy of Science and Art) founded in Zagreb, capital of Croatia, in 1876. During the rule of the collaborationist government of the Croatian Nazi state (1941-1945) the Academy became the Hrvatska akademija znanosti $i$ umjetnosti (Croatian Academy of Science and Art). After WW II its original name was restored 
for several decades, but the word Yugoslav was again replaced by Croatian in 1991 to underscore the newly acquired Croatian independence.

Renaming of the former state-owned businesses has been impacted by the process of privatization in that it has considerably diminished the appearance of ethnonyms and local personal names in the new names of these businesses particularly if the new owners are international companies. The names of public institutions, however, have resisted this trend.

Still, some names could not be changed by political will and power. The Serbian soccer teams Partizan (Partisan) and Crvena Zvezda (Red Star) have preserved their post-WW II names because it was rightly assumed that their fans would never accept their favorite team's name change. However, in Croatia, the most popular Zagreb soccer team Dinamo suffered two almost consecutive name changes. First, its pre-WW II name Građanski (Citizens) was restored in 1992 in order to wipe out any association with the team's Yugoslav past, and then, in 1993 it was renamed again and became Croatia Zagreb. Finally, the team's fans, who were otherwise the most fervent supporters of the Tudman's nationalist regime of the 90s, took matters into their own hands and staged a series of protests which forced the authorities to reinstitute Dinamo as the team's name.

Anthroponymy has been affected by the political changes as well. For example, during WW II and especially upon its end, the names that evoked affirmation of peace were particularly popular. Hence, there was a tide of compound names such as Ratomir (male), and Ratomirka and Mirjana (female). "Rat" means 'war' in Serbian, while "mir" means 'peace'. After the war many children were named after the names of places where the most notable Partisan victories took place. So, for example, a number of girls were called Sutjeska which is the name of the river where a battle against the Germans was fought and won. Along similar lines of thought parents picked names for their kids such as Slobodan and Slobodanka (male and female versions of the English personal name Liberty, as "sloboda" in Serbian means 'freedom'). As could be expected, in the post-war period girls were often named Nada (Hope), while there were very many boys who were named Vladimir after V. I. Lenin. There were also quite a few unfortunate choices of girls' names including, but not limited to Staljinka (after Josif V. Stalin), Mašinka (after the automatic machine gun), Molotovka (after a notorious Soviet minister of foreign affairs), Kolhoska (after the Soviet model of a farming commune called "kolhos"), etc. Names that appeared in the post-war movies, particularly war epics were also a source of personal names of the day. For example, only two girls had been named Slavica in the course of 12 years before the film Slavica (named after a character in the movie) was released as the first Yugoslav war epic made after WW II. After the movie premiered, 34 girls were named Slavica in a little over a year (see, Aleksandar Kostić's interview of August 31, 2007). 
The political changes of the 90s were reflected in the anthroponyms as well. The number of children who were given compound personal names whose first element is an ethnonym was on the rise. For example, names like Srbobran ('defending Serbs') and Srbislav ('celebrating Serbs') became popular. Also, old names, particularly those associated with historic figures, such as Nemanja and Dušan (the names borne by two medieval Serbian kings) became quite frequent. However, urban families have been very careful not to give their offspring any names which might smack of "peasants" choice" or very old names regarded as antiquated. Similarly, Albanian families often opt for the names that date back from their assumed Illyrian past. Such names are Ilir and Teuta, for example. They also seem to favor abbreviated ethnonyms such as Albin. All of the above names belong to the pool of anthroponyms which come and go. This tide is always initiated by political changes as political authorities, the church and other religious communities use all available means to influence parents' choice of names for their offspring. Today, however, these anthroponyms are in fierce competition with international names. Therefore, it is fair to say that, in general, archaic and ethnonym-based anthroponyms are an addition to toponyms which demonstrates the ethnic, religious and political identity or affiliation of parents.

\section{[6] ENDNOTE}

In April 2011 the municipality of Belgrade decided to split the Bajo Pivljanin street in three parts; the first one with the same name, the second getting name of Slavko Ćuruvija, a journalist killed by Security Service in April 1999, and the third one of Diana Budisavljević, a woman organising the rescue of children from Ustaša extermination camp Jasenovac during WW II. The discussion is still going on if the new bridge over river Sava should be called after general Dragoslav Mihajlovic, the commander of pro-German tchetnik forces during WW II. In the Serbian town Novi Pazar, with primarily Muslim population, there is now a conflict between Muslims and Serbs on naming one square after Isa-beg Isaković, the Turkish officer who founded the town in 1461. At the same time the municipality of Split in Croatia wanted to name one street after general Ante Gotovina, just judged to 24 years prison by the International Criminal Tribunal in Hague for organised war crimes against Serbs in 1995.

\section{REFERENCES}

Andersson, T. 1994. Ortnamnens existentiella villkor [The existential conditions of place-names]. In Ulfsparre, Göran (ed.). Ortnamn värda att vårda: Föredrag från Riksantikvarieämbetets symposium Ortnamnskultur, Stockholm 5-7 maj 1993, 7-19. Stockholm: Riksantikvarieämbetet. 
Azaryahu, M. 1991. Von Wilhelmplatz zu Thelmannplatz: Politische Symbole im öffentlichem Leben der DDR. Gerlingen: Bleicher Verlag. (Schriftenreihe des Instituts für Deutsche Geschichte, Universität Tel Aviv; 13).

Butenschøn, N.A. 1993. Politics of ethnocracies: strategies and dilemmas of ethnic domination. Oslo: Institutt for statsvitenskap, Universitetet i Oslo.

Contrast-PlanPlus10. 2008. Contrast-planplus 10. Beograd: Contrast. (Electronic maps).

David, J. 2011. Commemorative Place Names - Their Specificity and Problems. Names 59, No. 4. 214-228.

Dulović, V. 2004. Nazivi beogradskih ulica i trgova kao ogledalo ideologija vladajućih sistema (1848-2002) [The Names of Streets and Squares in Belgrade as a Mirror of Ideology and Ruling Systems]. In Zbornik Beogradske otvorene škole: Radovi studenata 2002/2003, 63-83. Beograd: Beogradska otvorena škola.

Geografska. 2007. Geografska enciklopedija naselja Srbije [Geographical Encyklopaedia of Settelments in Serbia]. Beograd: RAS.

Golubović, V. 2006. Stari Beograd: topografski rečnik [Old Belgrade: Topographic Dictionary]. Beograd: BeoSing.

Hallaråker, P. 1997. Innføring i stadnamn; innsamling og gransking [Introduction to Place Names: Collection and Research]. Oslo: Universitetsforlaget.

Josić, N. 1996. O nazivima ulica Beograda (kao delu kulturno-istorijske baštine) [On the Names of Streets in Belgrade (as a Part of Cultural and Historical Heritage)]. In Odaloš, P. \& M. Majtán: Urbanonymá v kontexte histórie a súčasnosti. Materiály $z$ onomastického kolokvia. Banská Bystrica [Urbonyms in historical and contemporary context. Proceedings from onomastic meeting], 250-256. Bratislava: Pedagogická fakulta Univerzity Mateja Bela - Fakulta humanitných vied Univerzity Mateja Bela - Jazykovedný ústav L’udovíta Štúra Slovenskej akadémie vied.

Kriterijumi. 2003. Kriterijumi za odredivanje naziva trgova $i$ ulica u beogradu [place naming guidelines for belgrade]. Beograd: Sekretarijat za kulturu i Komisija za spomenike i nazive trgova i ulica.

Leko, M. 2006. Beogradske ulice i trgovi: 1872-2006 [Streets and Squares in Belgrad: 1872-2006]. Beograd: Zavod za udžbenike i nastavna sredstva.

Lietz, G. 2009. Ideologisch motivierte Ortsnamenkonflikte in Mitteleuropa. Namn og Nemne 57-92. 
Memić, N. 2008. Städte der Diskriminierung - kriegsbedingte Ortsnamenänderungen in Bosnien-Herzegovina 1992-1995. In Eller, N., S. Hackl and M. Pupták (eds.), Namen und ihr Konfliktpotential in europäischen Kontext: Regensburger Sympozium, 11. bis 13. April 2007, 105-119. Regensburg: Edition Vulpes (Regensburger Studien zur Namenforschung, Band 4).

Piškorec, V. 2008. Die Straßennamenänderungen in Kroatien Anfang der 1990er Jahre am Beispiel der Stadt Đurđevec. In Eller, N., S. Hackl and M. Pupták (eds.), Namen und ihr Konfliktpotential in europäischen Kontext: Regensburger Sympozium, 11. bis 13. April 2007, 121-132. Regensburg: Edition Vulpes (Regensburger Studien zur Namenforschung, Band 4).

Rihtman-Auguštin, D. 2000 [1995]. Ulice moga grada [The streets of my Town]. In Ulice moga grada, 37-60. Beograd: Čigoja štampa: Zemun: Biblioteka XX vek. First published in Vijenac 6.4.1995, nr. 23.

Stojanović, D. 2008. Kaldrma i asfalt: urbanizacija i evropeizacija Beograda 18901914 [Cobblestone and Tarmac: Urbanization and Europeization of Belgrade 1890-1914]. Beograd: Udruženje za društvenu istoriju.

Stojanović, N. L. et al. 2004. Ulice i trgovi Beograda. 1: A-M [Streets and Squares of Belgrade 1: A-M]. Beograd: Biblioteka grada Beograda.

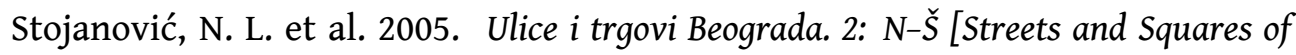
Belgrade 2: $N$-Š]. Beograd: Biblioteka grada Beograda.

Stolac, D. 1996. Nazivi ulica u rijeci u prošlosti i danas [names of streets in rijeka in the past and today]. In Odaloš, P. \& M. Majtán: Urbanonymá $v$ kontexte histórie a súčasnosti. Materiály z onomastického kolokvia. Banská Bystrica [Urbonyms in historical and contemporary context. Proceedings from onomastic meeting], 235-242. Bratislava: Pedagogická fakulta Univerzity Mateja Bela - Fakulta humanitných vied Univerzity Mateja Bela - Jazykovedný ústav L'udovíta Štúra Slovenskej akadémie vied.

Tarpley, F. 1996. Street Names as Signposts of World Cultures. In Steger, H. and H.E. Wiegand (Hrsg.). Name Studies: an International Handbook of Onomastics. (Handbuch zur Sprach- und Kommunikationswissenschaft. 11.2.), 1481-1499. Berlin, New York: Walter de Gruyter.

Tasić, N. M. Draganić (eds.). 1995. Istorija Beograda [The History of Belgrade]. Beograd: SANU; Draganić. 
AUTHOR CONTACT INFORMATION

From 1977 until his death Ljubiša Rajić served as professor at the University of Belgrade

Department of Scandinavian Studies

Studentski trg 3

RS-11000 Beograd

Serbia 